\title{
KEPEMIMPINAN PEDAGOGIS: MEMBANGUN KARAKTER GURU DAN SISWA MELALUI PEMODELAN PERILAKU POSITIF KEPALA SEKOLAH
}

\author{
${ }^{1}$ Yusaini \\ email: yusaini@iainlangsa.ac.id
}

\begin{abstract}
This article aims to explain how a school principal is able to shape the character of teachers and students through the application of pedagogical leadership in schools. Pedagogical leadership is leadership that is able to provide examples of positive behavior to all components in the school, both teachers, education staff and students. The discussion method was taken through a study of the library with various references relating to the formation of the character of the teacher and students, as well as their relationship with the principal's pedagogical leadership. The results of the literature review from various books and journals provide a clarity of the concept that to shape the character of teachers, education staff and students in schools a pedagogical leadership behavior model is needed, namely the principal's leadership that is able to provide role models through positive behavior, such as honesty, good heartedness, accustomed to the truth and mastered in the scientific field they have. The results of the study prove that the formation of teacher and student character is strongly influenced by the ability of principals to implement pedagogical leadership in a school-led environment.
\end{abstract}

Keywords: Pedagogical Leadership, Positive Characters, Teachers and Students.

\section{PENDAHULUAN}

Guru merupakan sosok pendidik yang memiliki tugas paling mulia dalam kehidupan berbangsa dan bernegara. Negara memberikan kewajiban kepada guru untuk mewujudkan cita-cita negara dalam mencerdaskan kehidupan dan generasi bangsa berkarakter. ${ }^{2}$ Guru memiliki tanggungjawab untuk membentuk karakter siswa di masa depan. Oleh karena itu, sekolah menjadi wadah tempat guru mendidik, membimbing, dan mencerdaskan siswa dengan berbagai pengetahuan dan keterampilan. Ketika guru di sekolah mampu menciptakan lulusan yang memiliki kecerdasan yang hebat dan karakter yang tepat, maka guru dipandang telah berhasil menciptakan lulusan yang baik. ${ }^{3}$.

Peran guru di sekolah tidak terlepas dari spektrum kepemimpinan. Artinya, guru yang berkarakter adalah guru yang mampu menunjukkan seluruh perilaku baik yang selanjutnya dijadikan sebagai contoh tauladan bagi siswa. Guru harus memiliki komptensi dan berkarakter positif sebagai sosok pemodelan perilaku di sekolah. Perilaku guru akan ditiru oleh siswa dalam berbagai aktivitas kehidupan. Guru harus memodelkan kejujuran dalam berbagai kesempatan. Ia

\footnotetext{
${ }^{1}$ Dosen Pada Fakultas Tarbiyah dan Ilmu keguruan (FTIK) Institut Agama Islam Negeri, Langsa dan Menjabat Sebagai Ketua LPM IAIN Langsa,

${ }^{2}$ Sabaruddin, "PARENTS' INVOLVEMENT IN IMPROVING CHARACTER OF CHILDREN THROUGH MATHEMATICS LEARNING,” Jurnal Ilmiah Peuradeun 6, no. 1 (2018).

${ }^{3}$ SUDIRMAN, H., "Strategi Implementasi Kurikulum: Suatu Kajian Perspektif Teori Di Sekolah Dasar," Adaara: Jurnal Manajemen Pendidikan Islam 9, no. 2 (2019): 936-51, https: //doi.org /10.35673/ ajmpi.v9i2.428.
} 
harus mencontohkan perilaku kebenaran dalam berbagai kegiatan. Guru yang menunjukkan perilaku baik kepada semua insan, dan guru harus mampu menunjukkan kemampuan di bidang keilmuannya. ${ }^{4}$

Keberhasilan guru untuk membangun perilaku positif sangat dipengaruhi oleh kepemimpinan Kepala Sekolah. Kepala sekolah merupakan pimpinan bagi semua sumber daya yang ada di sekolah. Kepemimpinannya sangat menentukan keberhasilan semua pihak yang di sekolah. Pembentukan karakter guru dan siswa sangat ditentukan oleh gaya kepemimpinan yang diterapkan kepala sekolah. Kepala sekolah haruslah orang yang terpilih, terpuji, berkarakter, berhati baik, jujur dan mampu mempengaruhi orang lain untuk mencapai tujuan pendidikan. ${ }^{5}$

Kepemimpinan perlu pengkajian komprehensif untuk menyatakan seseorang sukses dalam memimpin. Kepemimpinan merupakan sebuah variable yang dipegaruhi banyak faktor, seperti hubungan kerjasama antar individu, pola interaksi, kinerja, evektivitas kerja, dan perilaku orangorang dalam sebuah organisasi. Sekolah sangat membutuhkan seorang pemimpin yang mampu membangun perilaku orang lain menjadi baik. Kepala sekolah merupakan sosok pemimpin yang harus membangun karakter guru dan siswa di lingkunagan sekolah. Kepemimpinan kepala sekolah yang diinginkan di sekolah adalah kepemimpinan pedagogis. Sebab kepemimpinan pedagogis merupakan suatu pemikiran tentang kompetensi kepala sekolah yang diharapkan mampu mendorong penerapan strategi, gaya, teknik kepemimpinan menjadi efektif. Kemimpinan kepala sekolah yang diharapkan adalah seorang pemimpin yang memiliki kesadaran bahwa seorang pemimpin adalah juga seorang pendidik. ${ }^{6}$

Kepala sekolah harus menjadi seorang pemimpin dan pendidik bagi orang di sekelilingnya. Kepala sekolah harus mampu mengkonstruksi pendidikan bermutu. Pendidikan haruslah dapat membentuk karakter manusia menjadi terdidik. Salah satu cara yang harus dilakukan adalah dengan mengimplementasikan nilai-nilai pedagogis ke dalam seluruh aspek kehidupan ${ }^{7}$. Kepala sekolah bertanggungjawab dalam membangun karakter guru dan siswa dalam menjalankan tugas kepemimpinan. Kepala sekolah adalah pemimpin bagi guru dan siswa. Kepala sekolah yang sukses memimpin merupakan kepala sekolah yang melahirkan siswa cerdas dengan karakter yang baik, guru disiplin dan bertanggungjawab, dan orang lain di sekitarnya yang penuh keharmonisan, disiplin dan berkinerja.

\footnotetext{
${ }^{4}$ Ikhwan, "Pendidikan Karakter Dalam Perspektif Al-Qur'an," Mumtaz: Jurnal Studi Al-Qur'an Dan Keislaman 2, no. 1 (2019): 1-26, https://doi.org/10.36671/mumtaz.v2i1.17.

${ }^{5}$ SYAMSURIADI Syamsuriadi, "Self Management Concept Dalam Kepemimpinan Lembaga Pendidikan," Adaara: Jurnal Manajemen Pendidikan Islam 9, no. 2 (2019): 871-79, https://doi.org/10.35673/ajmpi.v9i2.423.

${ }^{6}$ Belferik Manullang, Kepemimpinan Pedagogis (Medan: Program Pascasarjana Unimed, 2006).

${ }^{7}$ Belferik Manullang, Perspektif Ilmu Pendidikan Membentuk Kepribadian (Medan: Universitas Negeri Medan, 2004).
} 
Saat ini tidak lagi mustihil jika guru berkarakter tidak baik dan tidak terdidik. Hal ini dapat saja terjadi apabila kepala sekolah bukan seorang pemimpin yang pedagogis. Kepala sekolah yang bukan pedagogis adalah kepala sekolah yang tidak mampu menunjukkan perilaku positif untuk dicontohkan oleh segenap unsur yang ada di sekolah, baik itu guru, tenaga kependidikan, maupun siswa. Apabila kepala sekolah tidak mampu menunjukkan contoh-contoh karakter yang baik kepada guru-gurunya, maka mungkin saja guru juga akan berkarakter buruk. ${ }^{8}$ Jika guru sebagai pemberi contoh tauladan tidak mampu menunjukkan perilaku baik, maka dapat dipastikan siswa akan terbiasa dengan perilaku buruk.

Kita dapat memisalkan contoh fenomena yang mungkin terjadi pada satu sekolah adalah kepala sekolah yang sering datang terlambat. Kemudian ia menginginkan gurunya untuk disiplin dengan tidak terlambat datang ke sekolah, dengan cara memberikan tanda cross (X) pada absen kehadiran guru. Selanjutnya, hari lain guru akan membalas dengan cara menunggu keterlambatan kepala sekolah untuk memberikan tanda cross absensi yang sama kepada kepala sekolah sebagai tanda bahwa kepala sekolah juga pernah terlambat ke sekolah. Ini merupaka aksi dan reaksi yang terjadi di satu sekolah. Jika ini terjadi sungguh merupakan contoh karakter kepala sekolah dan guru yang tidak mulia, dan ini dibangun oleh seorang kepala sekolah yang tidak memiliki kepemimpinan pedagogis. ${ }^{9}$

Kita sering mendengarkan pepatah yang dilantunkan oleh banyak orang. "Jika guru kencing berdiri, maka murid akan kencing berlari”. Mungkin pepatah ini dapat saja berlaku kepada guru di sekolah atau lembaga pendidikan lainnya. Jika kepala sekolah sering terlambat ke sekolah, mana mungkin guru-gurunya akan datang tepat waktu. Timbul pertanyaan baru, apakah mungkin sekarang ini guru juga memiliki karakter tidak mulia (berkarakter buruk) ini sulit untuk dijawab dengan jujur. Karena jika jawabannya ya, maka malapetaka akan menimpa negeri ini, malapetaka akan merusakkan bangsa, budaya, kesejahteraan, integritas, bahkan Agama.

Karakter adalah sesuatu yang penting dan tidak boleh hilang. Karakter tidak boleh rusak pada semua orang. Yang lebih terpenting lagi, karakter tidak boleh rusak pada kepala sekolah dan guru. Sebab kepala sekolah dan guru adalah pendidik karakter anak bangsa. ${ }^{10}$ Jika pabrik pembangun karakter sudah mati, maka suatu saat karakter akan hilang di negeri ini. Kita pasti semua setuju dengan pernyataan ini: "When Wealth is lost, nothing is lost. When health is lost,

${ }^{8}$ Siti Muhibah, "Model Pengembangan Pendidikan Karakter Melalui Pendidikan Agama Di Perguruan Tinggi: Studi Kasus Di Universitas Tirtayasa Banten," EDUKASI: Jurnal Penelitian Pendidikan Agama Dan Keagamaan 18, no. 1 (2020): 54-69, https://doi.org/10.32729/edukasi.v18i1.683.

${ }^{9}$ Danang Prasetyo dan Marzuki, "PEMBINAAN KARAKTER MELALUI KETELADANAN GURU PENDIDIKAN KEWARGANEGARAAN DI SEKOLAH ISLAM AL AZHAR YOGYAKARTA," Jurnal Pendidikan Karakter, 6 (2016): 215-31, https://media.neliti.com/media/publications/120670-ID-pembinaankarakter-melalui-keteladanan-g.pdf.

${ }^{10}$ Abdul Khobir, "Potret Pendidikan Karakter Di Kalangan Keluarga Nelayan," EDUKASIA ISLAMIKA, no. 4 (2019): 42-61, file:///C:/Users/WINDOWS 7/Downloads/2254-97-8156-1-10-20191224 (1).pdf. 
something is lost. When character is lost, everything is lost". ${ }^{11}$ Jika kekayaan sirna, sesungguhnya tidak ada yang hilang, jika kesehatan yang hilang, maka sesuatu telah hilang, jika karakter yang hilang, maka segala-galanya telah menghilang. Atas dasar inilah orang mulai berpikir bagaimana karakter dapat terbangun pada setiap jiwa genarasi masa depan, bahkan yang terpenting pada jiwa seorang pemimpin.

Jika karakter telah hilang, maka segala-galanya telah hilang. Setuju tidaknya pernyataan ini, kita merasakan dalam kehidupan. Kekayaan dan kesehatan belumlah menjadi sesuatu yang hilang bagi kita. Kerena harta dan kekayaan masih bisa dicari, dan sakit masih bisa diobati. Tetapi anak yang tidak hormat kepada guru dan kedua orang tua adalah sesuatu yang tidak dapat dibeli. Fenomena yang kita lihat dewasa ini, banyak anak-anak sekolah yang krisis karakter. Mereka tidak lagi memiliki karakter yang dapat dibanggakan sebagai pelajar. Mereka dapat melawan dan menyahuti guru tanpa kesopanan. Banyak siswa mencaci guru, apabila sesuatu yang ditegur tidak sesuai dengan selera mereka. Tentunya siswa yang krisis karakter seperti masih dalam jumlah yang kecil. Tapi kita bisa merasakan jumlah mereka terus bertambah. Oleh karena itu, guru dan kepala sekolah menjadi tugas berat dalam membangun karakter siswa. Bahkan guru pun perlu membangun karakter dirinya demi contoh teladan dalam mendidik karakter siswa.

Membangun karakter guru dan siswa sangat bergantung bagaimana cara kepala sekolah mengimplementasikan kepemimpinannya. Karakter guru akan terbangun apabila kepala sekolah mampu menunjukkan contoh perilaku baik disetiap pekerjaan dalam kepemimpinannya. Sehingga kepala sekolah menjadi sosok pimpinan yang bijak. ${ }^{12}$ Orang yang bijak adalah orang yang tidak memerintahkan orang lain bekerja, tetapi ia berusaha bekerja dengan baik sehingga pekerjaannya dapat dicontohkan oleh orang lain, sehingga orang lain mau bekerja. Hal ini identik dengan kepala sekolah yang tidak pernah memerintahkan guru-gurunya untuk datang ke sekolah tepat waktu, tetapi ia sendiri berusaha datang tepat waktu, sehingga guru merasa terganggu perasaannya jika datang terlambat. Hal ironis sering kita dijumpai adalah kepala sekolah memerintahkan guru untuk tidak terlambat ke sekolah, sementara ia sendiri sering terlambat. Cara yang seperti ini bukan tipe kepemimpinan pedagogis. Yang menjadi pertanyaan saat ini adalah dengan cara bagaimanakah seorang kepala sekolah harus memimpin terhadap orang-orang disekelilingnya agar karakter terbangun dalam diri siswa dan guru. Salah satu jawaban yang tepat adalah kepala sekolah harus memiliki kompetensi kepemimpinan pedagogis untuk memimpin, membangun karakter para guru dan siswa di lingkungan sekolah.

\footnotetext{
${ }^{11}$ Belferik Manullang, Kepemimpinan Pedagogis.

${ }^{12}$ Farrhatil, D.K., Dwi Hastuti, "PENGARUH METODE SOSIALISASI ORANG TUA DAN KONTROL DIRI TERHADAP KARAKTER SOPAN SANTUN REMAJA," Jurnal Pendidikan Karakter, 9 (2019): 192-203.
} 


\section{PEMBAHASAN}

\section{Kepemimpinan Kepala Sekolah}

Masa depan adalah harapan semua orang untuk berubah menjadi lebih baik. Masa depan perlu pemimpin yang bijak, berkarakter dan bertanggungjawab dalam melaksanakan kepemimpinan. Siapakah orang yang baik melaksanakan kepemimpinan? Apakah yang dimaksud kepemimpinan? Apakah kepala sekolah merupakan seorang pemimpin yang baik di sekolah?. Jawabannya sangat bergantung pada kepemimpinan yang ia pimpin.

Kepemimpinan berasal dari akar kata "pemimpin", yang memberikan maksud adalah orang yang dikenal oleh orang lain dan berusaha mempengaruhi para pengikutnya untuk meralisir visinya. Sementara Gamder (1990) menuliskan bahwa kepemimpinan adalah "Leadership is the process of persuasion or example by which an individual (or leadership team) induces a group to persue objectives held by the leader or shared by the leader and his followers". ${ }^{13}$ Pada bagian lain dalam penjelasan teori manajemen diberikah penjelasan bahwa kepemimpinan (leadership) adalah suatu proses pengarahan dan pemberian pengaruh pada kegiatan-kegiatan dari sekelompok anggota yang saling berhubungan dengan tugasnya. ${ }^{14}$

Dalam buku Manajemen ditulis oleh Stephen P. Robbins/Marry Coulter bahwa pemimpin adalah orang-orang yang mampu mempengaruhi orang lain dan memiliki wewenang manajerial. ${ }^{15}$ Banyak orang memiliki kemampuan untuk mempengaruhi orang lain. Dengan definisi ini, kita pun bisa menjadi seorang pemimpin. Tetapi apakah semua kita dapat menjadi seorang manajer? Seorang manajer tentu harus mampu memimpin. Selain itu, seorang manajer juga harus mampu merencanakan, melaksanakan, mengorganisasikan, dan mengontrol semua kegiatan terhadap orang-orang yang dipimpinnya. Maka, tidak semua pemimpin dapat menjadi seorang manajer.

Apakah kepala sekolah dapat dikatakan sebagai seorang manajer? Jawabannya adalah apabila mampu mempengaruhi orang-orang yang di sekelingnya dan mampu melaksanakan empat fungsi manajemen (perencaan, pelaksanaan, pengorganisasian dan pengontrolan), maka dapatlah dikatakan kepala sekolah adalah seorang manajer. Tetapi apakah kepala sekolah yang sudah ditugaskan oleh pemerintah telah memiliki kemampuan idealnya sebagai seorang manejer.

Fenomena yang sering terjadi di sekolah adalah banyak kepala sekolah mampu mempengaruhi orang-orang dalam system sekolahnya dengan baik. Tetapi pada sisi lain ia tidak memiliki kemampuan manajerial. Sehingga proses pendidikan dan pembelajaran dilaksanakan disekolah melahirkan berbagai kepincangan. Banyak guru tidak mempersiapkan RPP, silabus, dan media pembelajaran merupakan salah satu contoh tidak berfungsi perencanaan atau kontrolling

\footnotetext{
${ }^{13}$ Syaiful Sagala, Kemampuan Profesional Guru Dan Tenaga Kependidikan (Bandung: Alfabeta, 2011).

${ }^{14}$ Handoko, Manajemen, 2nd ed. (Yogyakarta: BPEE, 2002).

${ }^{15}$ S.P. dan Mary Coulter Robbins, Manajemen, kedelapan (Jakarta: PT. Indeks, 2007).
} 
kepala sebagai seorang manajer. Jika hal ini terjadi pada banyak sekolah, mustahil kita dapat memproleh kepemimpinan yang efektif untuk memajukan pendidikan daerah.

Kemajuan pendidikan sekolah membutuhkan sosok kepala sekolah yang efektif. Ciri-ciri kepala yang efektif menurut Tiong (1977) adalah (1) adil dan tegas dalam mengambil keputusan; (2) membagi tugas secara adil kepada guru; (3) menghargai partisipasi staf; (4) memahami perasaan guru; (5) memiliki visi dan berupaya melakukan perubahan; (6) terampil dan tertib; (7) berkemampuan dan efisien; (8) memiliki dedikasi dan rajin; (9) tulus dan ikhlas; (10) percaya diri. ${ }^{16}$

Untuk mengavaluasi keefektifan kepemimpinan kepala sekolah, maka sepuluh ciri-ciri yang dipaparkan Tiong dapat dirasakan dalam perjalanan pendidikan dan pembelajaran. Banyak sekolah dipimpin tidak efektif menimbulkan berbagai permasalahan. Keharmonisan orang-orang yang berada di sekolah tidak dapat terbina. Misalnya, kepala sekolah yang tidak tulus dan iklas, tidak memahami perasaan guru, dan tidak membagi tugas secara adil kepada guru. Tiga persoalan ini sering menaburkan benih konflik dan kekacauan, sehingga mengganggu keharmonisan sebuah sistem sekolah. Kepala sekolah tidak melindungi seorang guru yang tidak disiplin dalam menjalankan tugasnya sebagai seorang guru. Dengan demikian, hendaknya kepala tidak terlalu tertutup, melainkan lebih menyenangi sifat terbuka dan berdiskusi dalam menjalankan tugas-tugas sekolah secara bersama-sama. Syaiful Sagala, seorang guru besar Universitas Negeri Medan, juga menuliskan bahwa Kepala sekolah yang tertutup, tidak suka berdiskusi mengenai tugas-tugas, dan menangani sendiri hal-hal yang prinsip, tentu saja cenderung gagal dan tidak mendapat dukungan yang cukup dari para guru, konselor, dan orang tua peserta didik. ${ }^{17}$

Salah satu hasil penelitian yang temukan oleh Anwar $S$ tentang kepemimpinan transformasional memberikan kesimpulan bahwa seorang pimpinan menganjurkan dalam memperlakukan orang lain dengan penuh hormat dan mendorong bawahan untuk mencoba caracara baru dalam berbagai kegiatan. Mendorong bawahan untuk selalu bekerja keras dan professional serta mau melibatkan dan mendelegasikan pekerjaan pada bawahan agar pekerjaan jangan sampai dikerjakan sendiri. ${ }^{18}$ Mudah-mudahan kepala sekolah yang ada di daerah tidak lagi memborong semua pekerjaan sekolah secara sendiri. Karena kepemimpinan kepala sekolah seperti ini membuat tidak efektif dalam mengelola pekerjaan sekolah.

Kepala sekolah masa depan diharapkan sosok pemimpin yang mampu menciptakan efektivitas kerja dengan orang-orang yang dipimpinnya. Kepala sekolah hendaknya mampu mempengaruhi kinerja guru yang tinggi. Karena apapun alasannya, kinerja guru sangat

\footnotetext{
${ }^{16}$ Sagala, Kemampuan Profesional Guru dan Tenaga Kependidikan.

${ }^{17}$ Sagala.

${ }^{18}$ Anwar S, "Kepemimpinan Transformasional Majelis Dikdasmen Dalam Mengelola Sekolah," Jurnal Educandum Manajemen Pendidikan 1 (2008): 8.
} 
berpengaruh pada siapa yang memimpin. Jarang kita temukan guru mampu meningkatkan kinerja, apabila kepala sekolah sendiri sebagai pimpinan tidak memiliki kompetensi kepemimpinan efektif.

Mahdiansyah harahap menuliskan hasil penelitiannya dalam sebuah jurnal yaitu: terdapat hubungan yang berarti antara gaya efektivitas kepemimpinan kepala madrasah dengan kinerja guru di MTs Negeri Medan. ${ }^{19}$ Hasil penelitian ini memperkuat pemikiran kita salah bahwa satu faktor yang mampu meningkatkan kinerja guru adalah adanya sosok pemimpin yang efektif di tengahtengah guru dan siswa.

Dengan demikian pimpinan sekolah masa depan merupakan kepala sekolah yang memiliki ciri-ciri kepala sekolah efektif. Selain itu, juga memiliki perilaku teladan, dan mampu menjalankan fungsi manajemen dengan baik. Oleh karena itu, kepala sekolah merupakan orang pilihan dari guru terbaik. Bukan kepala sekolah yang diangkat dari hasil perjanjian kontrak politik, bukan kepala sekolah yang mampu membeli jabatan, dan bukan pula kepala sekolah berasal dari keluarga pejabat yang berwenang, sementara ia sendiri tidak memiliki jiwa kepemimpinan efektif, tidak memiliki perilaku baik dan tidak memiliki kompetensi sebagai manejer.

\section{Kepemimpinan Pedagogis}

Hidup adalah pendidikan, dan pendidikan adalah kehidupan. Selama masih adanya kehidupan, maka di sana mesti adanya pendidikan. Kehidupan ini akan menjadi pendidikan apabila memiliki nilai pedagogis, yaitu kekuatan dalam pembentukan karakter. Hidup dan kehidupan tidak lepas dari spectrum kepemimpinan. Artinya kepemimpinan adalah juga sebuah kehidupan. Oleh karena kepemimpinan adalah kehidupan, maka ia pun adalah pendidikan. Kepemimpinan menjadi pendidikan jika ia berhasil membentuk karakter bawahan, karena mengandung nilai pedagogis. ${ }^{20}$ Pendidikan yang ideal merupakan pendidikan yang mampu membagun nilai karakter. Pendidikan harus mampu menanamkan karakter secara bersamaan dalam pencapaian tujuan pendidikan. Orang bisa saja menempuh ilmu pengetahuan melalui sebuah lembaga pendidikan. Tetapi ilmu akan berguna jika karakter berada di dalamnya.

Orang yang berilmu pengetahuan tanpa dibarengi karakter akan menyedihkan. Ia akan merasakan gersang dan dahaga terhadap ilmu pengetahuan yang dimilikinya. Sebuah pepatah mengatakan: dikala ilmu membawa kehancuran, apagunanya kita berpengetahuan, dikala ilmu tidak membawa perubahan, percuma saja kita belajar sampai ke negeri Cina, dikala ilmu tidak lagi menjadi solusi permasalahan hidup, apa lagi yang harus diandalkan. ${ }^{21}$ Bayangkan saja jika banyak pemimpin, banyak para Doktor, dan mungkin juga professor yang menangani aktivitas hidup kearah kehancuran. Apakah mungkin orang seperti ini masih ada di tengah-tengah kehidupan kita?

\footnotetext{
${ }^{19}$ Mahdiansyah Harahap, "Kepemimpinan Transformasional Majelis Dikdasmen Dalam Mengelola Sekolah,” Educandum, Jurnal Manajemen Pendidikan 1 (2008): 76.

${ }^{20}$ Belferik Manullang, Kepemimpinan Pedagogis.

${ }^{21}$ Belferik Manullang.
} 
Jawabannya akan dapat diperoleh dengan melihat fenomena sehari-hari yang terjadi di tengahtengah kesibukan manusia.

Apabila fenomena aktivitas di lembaga-lembaga pendidikan yang dirasakan banyak membawa kehancuran, mungkin kita akan bertanya kembali, apakah orang-orang di lembaga tersebut tidak berpengetahuan. Tentu semua mereka berpengetahuan, hanya saja perilaku atau karakter merekalah yang membawa kehancuran. Banyak orang berilmu sanggup untuk melakukan korupsi, bahkan dengan ilmunyalah tergerak untuk melakukan koropsi. Kosupsi yang dilakukan oleh orang-orang yang berilmu sekarang ini juga dipraktekkan pada lembaga pendidikan. Yang kita sayangkan adalah untuk memenuhi kepentingan tertentu dapat membunuh hak peserta didik di lembaga pendidikan tersebut. Ketika ilmu membawa kehancuran, untuk apa kita berilmu pengetahuan. Mengingat kalimat ini, maka setiap orang yang berilmu harus tumbuhnya karakter dalam dirinya.

Pemimpin adalah orang yang berilmu tetapi juga berkarakter. Pemimpin sekolah tentunya kepala sekolah yang berilmu dan juga berkarakter. Apalagi kepala sekolah merupakan seorang pemimpin yang harus mampu membangun karakter guru dan siswa. Oleh sebab itu kepala sekolah selalu mencontohkan perbuatan baik kepada semua orang. Perbuatan baik yaitu menghargai diri sendiri dan menghargai orang lain dengan berbuat adil pada diri sendiri dan berbuat adil pada orang lain. Inilah etika dan karakter kehidupan yang dibutuhkan manusia yang berada di tengah-tengah masyarakat. ${ }^{22}$ Orang seperti inilah diharapkan dapat dijadikan kepala sekolah sebagai pemimpin pedagogis.

Karakter merupakan suatu kualitas pribadi yang bersifat unik menjadikan sikap atau perilaku seseorang yang satu berbeda dengan yang lain dalam sikap atau pribadi yang muncul ketika orang berinteraksi dengan orang lain dalam kehidupan sehari-hari. ${ }^{23}$ Apabila karakter seseorang baik, dapat dipastikan sikap atau perilakunya terhadap orang lain menjadi baik, perbuatannya menjadi baik, apa yang dilakukannya menjadi baik, apabila ia adalah seorang pemimpin ia menjadi pemimpin yang baik, dan apabila ia seorang kepala sekolah, maka ia menjadi kepala sekolah yang baik.

Kepala sekolah yang baik adalah kepala sekolah yang mampu memimpin dengan kepemimpinan pedagogis. Sebab, kepala sekolah harus melaksanakan fungsi manajemen sebagai manajer, tetapi juga harus menjadi pendidik karakter bagi guru, siswa dan stafnya. Kepala sekolah pedagogis sedapat mungkin mampu mempengaruhi guru untuk bekerja dengan membangun karakter bersama dalam lingkungan sekolah. Salah satu contoh, apabila pemimpin menuntut agar yang dipimpin memiliki kejujuran, tidak cukup hanya mengatakan betapa pentingnya kejujuran itu

\footnotetext{
${ }^{22}$ Syaiful Sagala dan Syawal Gultom, Praktik Etika Pendidikan Di Seluruh Wilayah NKRI (Bandung: Alfabeta, 2011).

${ }^{23}$ Syaiful Sagala dan Syawal Gultom.
} 
dalam menjalankan pekerjaan, atau seseorang akan sukses jika melakukan kejujuran, melainkan pemimpin menunjukkan komitmen tentang kejujuran dalam kehidupannya. ${ }^{24}$ Ternyata kepemimpinan pedagogis memerlukan sosok yang benar-benar memiliki jiwa yang berkarakter baik.

Kepemimpinan pedagogis biasanya bertindak tegas. Makna tegas, di sini ialah tegas yang rasional, tegas dengan kesadaran emosi, dan tegas untuk kebermaknaan holistik. Ketegasan tersebut harus dikendalikan oleh kebermaknaan holistik. Kepemimpinan pedagogis tidak dikendalikan oleh pertimbangan rasional atau emosional, tetapi oleh kecerdasan spiritual. Kepemimpinan seperti ini tidak hanya sekedar mampu membuat bawahan bersedia bekerjasama, melainkan terjadi transformasi nilai yang menyentuh pembentukan karakter mereka. Bahkan boleh disimpulkan bahwa kesediaan bawahan untuk bekerjasama tidak lagi karena faktor eksternal melainkan bersumber dari hatinya, motivasi internal, yakni karakter bawahan itu sendiri. Jadi kepemimpinan pedagogis adalah upaya mempengaruhi bawahan agar bersedia bekerjasama untuk mencapai tujuan organisasi melalui tindakan-tindakan rasional, kesadaran emosi dan kebermaknaan holistik. ${ }^{25}$

Perilaku kepemimpinan pedagogis memiliki nilai tinggi dalam memimpin sekolah. Karena yang dimaksud pimpinan pedagogis tidak hanya sebatas mampu mempengaruhi bawahannya untuk dapat bekerja sama untuk mencapai tujuan yang ingin dicapai sekolah. Melainkan guru, staf administrasi dan siswa diharapkan terjadi perubahan karakter, yakni sifat-sifat yang melekat dalam kepribadiannya. ${ }^{26}$ Sehingga, tanpa disadari loyalitas institusional mereka semakin mantap karena perubahan karakter. Sehingga perubahan kemajuan segenap bawahan akan menjadi kuat sebagai perubahan faktor internal sekolah, bukan karena kekuatan eksternal. Sekolah yang menjalankan segenap tugas dan kegiatan dengan dasar pembentukan karakter merupakan sekolah yang berjalan penuh keharmonisan. Sekolah ini biasanya memiliki sifat guru yang bekerja tanpa ada tekanan, penuh keikhlasan, tidak ada rasa takut, tidak ada kecemasan, melainkan mereka bekerja melaksanakan tugas dengan sungguh-sungguh karena mau melakukannya dengan dorongan hati mereka sendiri.

Fokus kepemimpinan pedagogis kepala sekolah adalah pembentukan karakter, sehingga bawahan memiliki sifat-sifat terpuji. Mereka akan memiliki motivasi kerja yang tinggi karena di dorong oleh motivasi internal yang ada dalam dirinya yang terbentuk oleh karakter. ${ }^{27}$ Sekolah yang dipimpin dengan fokus kepemipinan pedogogis akan memiliki guru dan siswa yang tidak hanya baik di tempat kerja ataupun di sekolah, tetapi mereka juga baik di tempat lain, di rumah, di tempat

\footnotetext{
${ }^{24}$ Belferik Manullang, Kepemimpinan Pedagogis.

${ }^{25}$ Belferik Manullang, Perspektif Ilmu Pendidikan Membentuk Kepribadian.

${ }^{26}$ Nopan Omeri, "Pentingnya Pendidikan Karakter Dalam Dunia Pendidikan," Manajer Pendidikan 9, no. 3 (2015): 464-68.

${ }^{27}$ Ahmad Yasser Mansyur, "Personal Prophetic Leadership," Jurnal Pendidikan Karakter Tahun III, no. 1 (2013): 15-27.
} 
bisnis, di pasar, di forum, dalam pergaulan, dan diberbagai dimensi kehidupan. Hal ini terjadi, karena mereka memiliki karakter positif, sehingga tanpa disadari perilaku baik akan melekat disemua aktivitas. Seorang guru baik tidak hanya baik kepada kepala sekolah, tetapi ia baik kepada anak-anaknya, baik dengan siswanya, baik dengan isterinya, dan baik dengan semua orang.

Guru besar Unimed menulis seuntai syair sebagai cermin orang yang berkarakter sebagai berikut: Di dalam rumah, mereka menunjukkan kebaikan, di dalam bisnis, mereka menunjukkan kejujuran, di dalam masyarakat, mereka menunjukkan kesopanan, di dalam pekerjaan, mereka menunjukkan kecermatan, di dalam permainan mereka menunjukkan sportivitas, dan terhadap yang beruntung mereka memberikan selamat, terhadap yang lemah mereka menolong, terhadap yang jahat, mereka bertahan untuk tidak ikut jahat, terhadap yang kuat mereka percaya, terhadap yang menyesal, mereka bisa memaafkan, dan terhadap rahmat mereka bersyukur. ${ }^{28}$

Mari kita bayangkan seandainya orang-orang yang ada di sekeliling kita memiliki jiwa karakter, tumbuh dan ramai di tengah-tengah masyarakat, pasti hidup akan menjadi damai, sekolah penuh ketentraman, guru penuh kewibawaan, siswa penuh jiwa hormat, sopan dan cerdas, kepala sekolah penuh perasaan dan tanggungjawab, tujuan sekolah pun akan mudah mencapai tujuan tanpa harus bersusah payah. Tetapi lingkungan sekolah seperti ini mulai sulit dijumpai orang. Tetapi bagaimana untuk masa depan? Inilah yang perlu dipikirkan oleh semua orang. Kepala sekolah dan guru menjadi peranan penting dalam membangun pendidikan yang berkarakter di sekolah, demi generasi masa depan.

Sekolah menjadi tempat untuk menempa, membina, dan membangun karakter generasi bangsa, selain oleh kedua orang tua dan masyarakat. Kepala sekolah harus mampu membangun kepemimpinan pedagogisnya dalam pembentukan karakter siswa. Sekolah menjadi media paling penting dalam membangun karakter. Sebab sekolah tempat menimba pengetahuan dan merubah perilaku dan kecerdasan siswa. Perubahan ini akan dilakukan dengan suatu proses panjang dengan mempraktik perilaku sesuai tujuan pembelajaran yang ingin dicapai. Maka, menjadi hal yang tepat bahwa pembentukan karakter lebih banyak dibentuk dan dibangun dalam proses pendidikan.

Kepala sekolah memiliki tugas intensif untuk membangun karakter generasi bangsa di sekolah. Karakter generasi muda sudah berada pada titik yang sangat mengkhawatirkan. Moralitas bangsa, sudah lepas dari norma, etika agama, dan budaya luhur. Dimana mana seks bebas menjadi fenomena tanpa bisa dibendung sedikitpun dan sudah menjadi praktik modern tanpa adanya rasa malu. Salah satu hasil penelitian ditemukan sebanyak 42,3\% pelajar di Cianjur telah berhubungan seks pranikah (Waspada, edisi 11 Februari, 2007). Selain itu, penelitian yang dilakukan di lima kota di tanah air sebanyak $16,35 \%$ dari 1.388 responden remaja mengaku telah melakukan hubungan seks di luar nikah atau seks bebas. Sebesar 42,5\% responden di Kupang Nusa Tenggara Timur (NTT) melakukan hubungan seks di luar nikah. Sedangkan 17\% responden di Palembang,

\footnotetext{
${ }^{28}$ Belferik Manullang, Kepemimpinan Pedagogis.
} 
Sumatra selatan, Tasik Malaya, dan Jawa Barat juga mengaku melakukan tindakan yang sama. Bahkan di kota-kota besar lainnya, seperti Medan, Jakarta, Bandung Yogyakarta, dan Surabaya juga sangat tinggi, bahkan melebihi 50\%. Yang lebih mengejutkan untuk kota Yogyakarta, sekitar $97,05 \%$ remaja di sana telah melakukana seks bebas. ${ }^{29}$

Pertanyaan baru adalah apakah semakin bertambah umur bangsa ini semakin meningkat persentase generasi bangsa mempraktikan perilaku tidak bermoral? Hal terpenting dibalik pertanyaan ini, bagaimana kepimpinan pedagogis diterapkan dalam semua proses pendidikan. Pendidikan adalah proses pembentukan karakter positif dengan menggunakan alat pendidikan yang terjadi dalam lingkungan sosial. Yang membuat pendidikan memiliki nilai pedagogis adalah melekatnya alat pendidikan pada pendidikannya. Kepemimpinan pedagogis adalah kepemimpinan dimana pemimpin memiliki alat pendidikan sehingga perilakunya memiliki nilai-nilai pedagogis. Alat pendidikan yang dimaksud adalah kesabaran, kewibawaan, keteladanan, penguatan, kasih sayang, ketulusan, dan ketegasan pedagogis. ${ }^{30}$

Guru Besar pada Program Pascasarjana Unimed Medan menjelaskan kerpemimpinan pedagogis memiliki kemampuan menyelidiki kekuatan dan kelemahan sendiri dan belajar bagaimana cara menonjolkan segi positif dan menyingkirkan segi negative. Kepemimpinan pedagogis melatih diri untuk memahami orang lain dan dapat menyadari bahwa hanya karena perbedaan, bukan berarti mereka salah. Seorang pimpinan pedagogis harus mampu menghargai emosi diri sendiri, dan juga emosi orang lain sekalipun emosi itu bersifat negative. Pemimpin pedagogis adalah pelatih emosi, sehingga melalui kepemimpinannya orang yang dipimpin lambat laun semakin cerdas emosinya. ${ }^{31}$

Kepemimpinan pedagogis perlu dimiliki oleh semua kepala sekolah. Jiwa kepala sekolah hendaknya memiliki sifat kepimpinan pedagogis. Kepala sekolah pedagogis lambat laun mampu membangun karakter guru dan siswa ke arah positif. Jika semua orang di sekolah penuh dengan sifat pedagogis, berperilaku baik, maka sekolah bergerak dan terbangun dengan cinta damai, sopan dan bertanggungjawab. Kepemimpinan seperti inilah diharapkan dipimpin oleh pemimpin pedagogis di setiap sekolah.

\section{Membangun Karakter Guru dan Siswa di Sekolah}

Kata karakter dapat ditemukan dari kata latin karakter, kharassein, dan kharax, yang maknanya "tools for marking", "to engrave", dan "Pointed stake". Kata ini mulai banyak digunakan dalam bahasa perancis caractere pada abad ke-14 dan kemudian masuk dalam bahasa inggris menjadi character, sebelum akhirnya menjadi bahasa Indonesia karakter (Harefa, dalam Syaiful Sagala, 2011). Dalam kamus Poerwadarmita, karakter diartikan sebagai tabiat; watak; sifat-

\footnotetext{
${ }^{29}$ Belferik Manullang, Perspektif Ilmu Pendidikan Membentuk Kepribadian.

${ }^{30}$ Belferik Manullang, Kepemimpinan Pedagogis.

${ }^{31}$ Belferik Manullang.
} 
sifat kejiwaan; akhlak atau budi pekertiyang membedakan seseorang dari pada yang lain. Membangun karakter (character building) merupakan proses membentuk diri, sehingga unik, dan menarik, dan mampu tampil beda. Sehingga orang-orang yang berkarakter dapat dibedakan satu dengan yang lainnya. ${ }^{32}$

Sedangkan pendidikan merupakan proses internalisasi budaya ke dalam diri seseorang dan masyarakat sehingga membuat orang dan masyarakat jadi beradab. Pendidikan bukan merupakan sarana transfer ilmu pengetahuan saja, tetapi lebih luas lagi yakni sebagai sarana pembudayaan dan penyaluran nilai (enkulturisasi dan sosialisasi). Anak harus mendapatkan pendidikan yang menyentuh dimensi dasar kemanusiaan. Dimensi kemanusiaan itu mencakup sekurang-kurangnya tiga hal paling mendasar, yaitu: (1) afektif yang tercermin pada kualitas keimanan, ketakwaan, akhlak mulia termasuk budi pekerti luhur serta kepribadian unggul, dan kompetensi estetis; (2) kognitif yang tercermin pada kapasitas pikir dan daya intelektualitas untuk menggali dan mengembang-kan serta menguasai ilmu pengetahuan dan teknologi; dan (3) psikomotorik yang tercermin pada kemampuan mengembangkan keterampilan teknis, kecakapan praktis, dan kompetensi kinestetis. ${ }^{33}$

Target pembangunan karakter di sekolah adalah siswa. Guru dan kepala sekolah memiliki tugas berat untuk membangun karakter siswa. Karakter siswa selama ini menjadi sorotan publik. Hal ini disebabkan perilaku yang ditunjukkan siswa di tengah-tengah masyarakat sungguh memprihatinkan. Siswa sudah mulai tidak lagi hormat kepada masyarakat, guru dan bahkan kepada kedua orang tuanya. Jika kita melihat siswa bersepeda motor di jalan raya dengan ban depan yang diangkat ke atas, siapa yang akan di salahkan? Apakah orang tuanya, guru, atau masyarakat? Jika datang guru untuk menegur dengan cara mendidik, mungkin saja kenalpot sepeda motornya akan dihadapkan ke muka gurunya, untuk menunjukkan bahwa guru tidak keuntungan bagi dirinya.

Fenomena lain dapat diceritakan, ketika upacara bendera hari senin di sutu sekolah sedang berlangsung, siswa yang terlambat datang ke sekolah dimintakan oleh gurunya untuk berbaris di luar pagar sekolah dengan pintu gerbang tertutup. Tiba-tiba sebagain guru juga datang terlambat, dan dibolehkan masuk oleh guru lain yang menjaga pintu gerbang. Perilaku ini selalu diperhatikan siswa yang terlambat di setiap hari senin. Siswa bertanya dalam hatinya, kalau kita yang terlambat dilarang masuk, kalau bapak atau ibu guru yang terlambat dibolehkan masuk. Ini menjadi satu contoh bahwa keteladanan belum mampu dimodelkan oleh guru kepada siswa. Bagaimana mungkin siswa berkarakter positif apabila karakter guru negative.

Padahal kita dangat merindukan siswa berkarakter, guru berkarakter, pemimpin berkarak, dan semua orang berkarakter, agar kedamaian dapat dirasakan. Bukankah bila ada cahaya di dalam jiwa, ada kecantikan di dalam pribadi, bila ada kecantikan di dalam pribadi, ada harmoni di dalam

\footnotetext{
${ }^{32}$ Sagala, Kemampuan Profesional Guru Dan Tenaga Kependidikan.

${ }^{33}$ Sagala.
} 
rumah, bila ada harmoni di dalam rumah, ada ketertiban di dalam masyarakat dan Negara, bila ada ketertiban di dalam masyarakat dan Negara, ada kedamaian di dunia.

Agar kedamaian bisa diperoleh dalam hidup, maka perlu membangun kembali karakter siswa, peserta didik, dan orang-orang di sekitar kita. Lalu siapa yang kita salahkan jika siswa kita tidak berkarakter. Tentunya tidak ada yang slah, atau semuanya salah. Maka jalan yang lebih bermanfaat membangun karakter adalah dengan memperbaiki karakter anak-anak kita dalam keluarga, bila mungkin teman-teman dekat dan saudara kita. Ini adalah usaha paling baik perlu kita lakukan sesegera mungkin. Daripada kita harus menuding orang lain, pemerintah, lembaga pendidikan, sementara kita melepaskan tanggungjawab sebagai salah seorang pembentuk karakter dalam keluarga.

Siapa yang utama harus berubah agar karakter bangsa berubah? Jawaban ini akan terungkap melalui sebuah puisi singkat "Hasrat Untuk Berubah", sebagai berikut: Ketika aku masih muda dan bebas berkhayal, aku bermimpi ingin mengubah dunia, seiring dengan bertambahnya usia dan kearifan ku, kudapati bahwa dunia tidak pernah berubah, maka cita-cita itupun agak ku persempit, lalu kuputuskan untuk hanya mengubah negeri ku, namun nampaknya, hasrat itupun tidak berhasil, ketika usia ku semakin senja, dengan semangat ku yang masih tersisa, kuputuskan untuk hanya mengubah keluargaku, orang-orang yang paling dekat dengan ku, tetapi celakanya, merekapun tidak mau berubah, dan kini sementara aku berbaring saat ajal menjelang, tiba-tiba kusadari, andaikan yang pertama-tama ku ubah adalah diriku, maka dengan menjadikan diriku sebagai teladan, mungkin aku bisa mengubah keluargaku, lalu berkat inspirasi dan dorongan mereka, bisa jadi akupun dapat memperbaiki negeriku, kemudian siapa tahu, bahkan aku bisa mengubah dunia. ${ }^{34}$ Dari puisi ini dapat diambil hikmah adalah jadikan diri sebagai orang pembangun dan pembentuk karakter dimulai dengan memperbaiki diri kita sendiri. Dengan karakter diri yang baik akan menjadi contoh teladan dalam membangun karakter orang-orang di sekeliling kita.

\section{KESIMPULAN}

Fokus kepemimpinan pedagogis adalah pembentukan karakter, sehingga bawahan memiliki sifat-fifat yang positif. Kepala sekolah yang pedagogis lambat laun mampu membangun karakter guru dan siswa kepada perilaku positif. Jika semua orang di sekolah penuh perilaku pedagogis, berperilaku baik, maka sekolah bergerak dan tumbuh dengan cinta damai, sopan dan bertanggungjawab. Dengan kepemimpinan pedagogis akan membentuk kepribadian guru dan siswa yang berkarakter dengan perilaku yang jujur, berhati baik, terbiasa dalam kebenaran dan berkompeten di bidangnya.

\footnotetext{
${ }^{34}$ Belferik Manullang, Kepemimpinan Pedagogis.
} 
Agar kedamaian bisa diperoleh dalam hidup, maka perlu membangun kembali karakter siswa, peserta didik, dan orang-orang di sekitar kita. Jalan yang lebih bermanfaat untuk membangun karakter adalah dengan cara memperbaiki karakter diri kita sendiri, kemudian memperbaiki karakter anak-anak kita dalam keluarga, bila mungkin teman-teman dekat dan saudara kita. Ini adalah usaha paling baik perlu dilakukan sesegera mungkin, dari pada harus menuding orang lain, pemerintah, dan instansi pendidikan.

\section{DAFTAR RUJUKAN}

Abdul Khobir. "Potret Pendidikan Karakter Di Kalangan Keluarga Nelayan." EDUKASIA ISLAMIKA, no. 4 (2019): 42-61. file:///C:/Users/WINDOWS 7/Downloads/2254-97-8156-110-20191224 (1).pdf.

Anwar S. "Kepemimpinan Transformasional Majelis Dikdasmen Dalam Mengelola Sekolah." Jurnal Educandum Manajemen Pendidikan 1 (2008): 8.

Belferik Manullang. Kepemimpinan Pedagogis. Medan: Program Pascasarjana Unimed, 2006.

_ Perspektif Ilmu Pendidikan Membentuk Kepribadian. Medan: Universitas Negeri Medan, 2004.

Danang Prasetyo dan Marzuki. "PEMBINAAN KARAKTER MELALUI KETELADANAN GURU PENDIDIKAN KEWARGANEGARAAN DI SEKOLAH ISLAM AL AZHAR YOGYAKARTA." Jurnal Pendidikan Karakter, 6 (2016): 215-31. https://media.neliti.com/media/publications/120670-ID-pembinaan-karakter-melaluiketeladanan-g.pdf.

Farrhatil, D.K., Dwi Hastuti, dan Diah Krisnatuti. "PENGARUH METODE SOSIALISASI ORANG TUA DAN KONTROL DIRI TERHADAP KARAKTER SOPAN SANTUN REMAJA." Jurnal Pendidikan Karakter, 9 (2019): 192-203.

Handoko. Manajemen. 2nd ed. Yogyakarta: BPEE, 2002.

Ikhwan, Ikhwan. "Pendidikan Karakter Dalam Perspektif Al-Qur'an." Mumtaz: Jurnal Studi AlQur'an Dan Keislaman 2, no. 1 (2019): 1-26. https://doi.org/10.36671/mumtaz.v2i1.17.

Mahdiansyah Harahap. "Kepemimpinan Transformasional Majelis Dikdasmen Dalam Mengelola Sekolah." Educandum, Jurnal Manajemen Pendidikan 1 (2008): 76.

Mansyur, Ahmad Yasser. "Personal Prophetic Leadership." Jurnal Pendidikan Karakter Tahun III, no. 1 (2013): 15-27.

Muhibah, Siti. "Model Pengembangan Pendidikan Karakter Melalui Pendidikan Agama Di Perguruan Tinggi: Studi Kasus Di Universitas Tirtayasa Banten." EDUKASI: Jurnal Penelitian Pendidikan Agama Dan Keagamaan 18, no. 1 (2020): 54-69. https://doi.org/10.32729/edukasi.v18i1.683.

Omeri, Nopan. "Pentingnya Pendidikan Karakter Dalam Dunia Pendidikan." Manajer Pendidikan 9, no. 3 (2015): 464-68.

Robbins, S.P. dan Mary Coulter. Manajemen. Kedelapan. Jakarta: PT. Indeks, 2007.

Sabaruddin. "PARENTS' INVOLVEMENT IN IMPROVING CHARACTER OF CHILDREN THROUGH MATHEMATICS LEARNING.” Jurnal Ilmiah Peuradeun 6, no. 1 (2018).

Sagala, Syaiful. Kemampuan Profesional Guru Dan Tenaga Kependidikan. Bandung: Alfabeta, 2011. 
Sudirman, H. SUDIRMAN. "Strategi Implementasi Kurikulum: Suatu Kajian Perspektif Teori Di Sekolah Dasar." Adaara: Jurnal Manajemen Pendidikan Islam 9, no. 2 (2019): 936-51. https://doi.org/10.35673/ajmpi.v9i2.428.

Syaiful Sagala dan Syawal Gultom. Praktik Etika Pendidikan Di Seluruh Wilayah NKRI. Bandung: Alfabeta, 2011.

Syamsuriadi, SYAMSURIADI. "Self Management Concept Dalam Kepemimpinan Lembaga Pendidikan." Adaara: Jurnal Manajemen Pendidikan Islam 9, no. 2 (2019): 871-79. https://doi.org/10.35673/ajmpi.v9i2.423. 